\title{
BISHOP ALBERT BERECZKY (1893-1966) AND THE REVIVAL MOVEMENT: ALBERT BERECZKY'S CONVERSION
}

\author{
GÁBOr J. LÁNYI* \\ Gáspár Károli Reformed University
}

\begin{abstract}
This original research paper discusses Bishop Albert Bereczky's (1893-1966) first contacts with revivalism, especially his spiritual conversion experience during his adolescent years. Albert Bereczky, Bishop of the Danubian Church District from 1948 to 1958, was one of the most significant, and yet controversial persons of the Reformed Church in Hungary during the 20th Century. From a popular preacher of the Revival Movement of the 1920s, church planter of the 1930s, rescuer of Jews during the War, he became the tool of state interest of the Communist regime in the 1950s. This paper sorts out the origins of his turn to the revival movement, like his troubled childhood, the emotional and financial insecurity of an illegitimate child, his troubled relationship with his biological father, the positive example of his stepfather, and his deviant adolescence behavior. By showing examples of his personal accounts the paper discusses whether Bereczky went through a 'sudden' or a 'gradual' conversion experience.
\end{abstract}

KEYWORDS: Revivalism, John Mott, Albert Bereczky, History of the Reformed Church in Hungary during Communism, conversion experiences

On a conference recently, I gave a lecture about Sándor Fekete, who as the dean of the Budapest-North Church County in the 1950s was one of the most effective agents of the Hungarian Reformed Church's adjustment to the communist state policies. By his questionable methods, almost 30 pastors within the Danubian Church District were transferred to another congregation, sent to retirement or threatened to resign from their pastoral positions. [Ráday Levéltár, Alb fond, 2048/1956]. Finally, at the beginning of 1956, Fekete was also forced to leave as a result of a fabricated disciplinary action, which was part of the delayed reforms of Bishop Bereczky. [For the detailed description of the case see: Ráday Levéltár, Alb fond, 9/1958.] After my lecture, somebody from the audience, one of the recent executives of our Church District, shared that her mother became a born-again Christian by a sermon delivered by Sándor Fekete. Fekete, now (in)famous as the formidable agent of the

* GÁbOR J. LÁNYI (PhD 2011, Gáspár Károli Reformed University) is an Associate Professor of Church History at Gáspár Károli Reformed University in Budapest, Hungary. Email: lanyi.gabor@kre.hu. 
political church order of the 1950 s was also a longstanding activist of the revival movement of the post-war Hungarian Reformed Church.

This recent experience of mine leads us to one of the most difficult and disturbing questions of twentieth century Reformed Church history; how come so many members of the revival movement became associated with the socialist and communist ideals, and how could they so easily become the promoters of the communist state interest within the church government? This phenomenon did not escape the attention of some other researchers (Kovács 2019: 141-162). We even have a term for this phenomenon; it is the 'church political monopolization of the revival movement' (Kiss 2006: 1357). Besides Fekete, its main representatives were István Finta, Benő Békefi, Imre Kádár, János Péter, the moderate József Farkas and, as its figurehead, Bishop Albert Bereczky can be mentioned as well.

Apparently, many advocates of the revival movement of the inter-war and early post-war period became active partakers in the communist state's control over the church. Still, the majority of the revivalists did not find their place in the new establishment. After the state's abolition of the official revival organizations - which were portrayed as the agents of harmful Western ideological influence - the remnants of their members were forced into internal exile within the church (Ladányi 1999: 124). Under the pressure of the communist social policy, which tried to annihilate any form of self-government, free thinking and free speech (Kovács 2012: 407), the compromised church government tried to secure its control over the voluntarily organized revivalist groups and annihilate them one after the other. The so-called 'Brotherly Message' of Bishop Bereczky and the new Mission Regulation issued on 29 February 1952 almost entirely extinguished the long-standing tradition of voluntary lay ministry within the Reformed Church.

After World War II, Albert Bereczky became the natural leader of those church persons who criticized the inter-war conditions of the Reformed Church, expressed the church's responsibility in the political process resulting in the lost war and the extermination of the Jews. This group also had a neutral or even positive attitude towards the socialist transition of Hungary. Bereczky played a connective role between the different social, political and ideological clusters of the Reformed Church and its revival movement. The post-war revival movement consisted of many slightly different viewpoints. We must mention the 'rural' revivalists, such as Sándor Karácsony, or Bereczky's father-in-law János Victor; the ‘urban' reformers, such as Sándor Joó or Imre Szabó, dean of the then unified Budapest Church County; the leftist and politically minded later opportunists, like Békefi, Fekete and Finta; and the moderate and traditionalist officials such as Gyula Muraközy, Imre Révész or Bishop László Ravasz (Gombos 1992: 19). On some level, all these circles acknowledged Bereczky's qualities as a church-planter, revival evangelist and 
potential leader of the church. However, Bereczky's leftist revivalist supporters, by the consent of Bereczky, inevitably challenged the church establishment functioning under the jurisdiction of Ravasz. Experiencing the rise of communist dominance, it became apparent that it would only be a matter of time before the Ravasz management had to give way to those who could better serve the new political interest. Bereczky had an active role in the negotiations that convinced Ravasz to resign. Due to his support by the leftist revivalists and the then silent consent of the moderate rural and urban revivalists, it became obvious that Bereczky was the right person to replace Ravasz in the leadership of the Reformed Church. After the 'guard-mounting' (Őrségváltás) between Ravasz and Bereczky in 1948, Bereczky gradually lost control over the opportunistic persons within his own church leadership, whose financial and moral abuses disturbed the Reformed community. When Bereczky realized that the arrogant and ambitious members of his government compromise his leadership, from 1954 on, he made a desperate attempt to drive them out of power by the help of his newly elected deputy, László Pap, Dean of the Budapest Seminary (Pap 1992: 115). Even if they achieved to ban Fekete and Finta from the church leadership, Bereczky's reforms came too late.

The moderate revivalists and mostly those who became disappointed by Bereczky's 'narrow road' church policy formed their own reform efforts, which turned into the Reformed Revival Movement later and came forward during the revolutionary events of October 1956 and reinstated the Ravasz church government (Barcza 1999: 176). Bereczky, who suffered a stroke earlier in 1956, lost his control over the events entirely (Nagy 1994: 115-117). After the military suppression of the Revolution, the partly incapacitated Bereczky was reinstalled as Bishop by the State Office for Church Affairs so that the continuity between the Kádár Regime and the pre-revolution order became underlined (Kiss 2006: 1406-1407).

As we could see, Bereczky's personality and his association with the revival movement is crucial to understand the main developments of the 1950s' church politics. But when did it all begin? Since the present conference only deals with the historical events taking place until 1918, the goal of this paper is to represent Bereczky's first contacts with revivalism, and especially his spiritual conversion experience during his adolescent years (Siba 2009: 67-78).

Albert Bereczky was born in Budapest in 1893. His mother was the Baroness Mária Pongrácz, a descendant of an impoverished aristocratic family, who served as housekeeper for Count Albert Apponyi (1846-1933), the wellknown politician and diplomat of the era. However even the Bereczky family is divided in this question until today, by circumstantial evidence we can strongly assume that Count Albert Apponyi was Albert Bereczky's biological father. Being an illegitimate child could result in a troubled childhood. 
Bereczky's illegitimacy could evolve into a feeling of dignity and superiority, and a feeling of being unnoticed, neglected and excluded, at the same time. One of the keys to understanding Bereczky's personality is to recognize his controversial and ambiguous relationship to his supposed biological fatherthe neglection which manifested in a compulsion to conform. Bereczky always wanted to prove himself, always wanted to show his sufficiency, and earn others' attention and approval.

After the early death of the old husband of his mother, Endre Bereczky, whose name Albert Bereczky bore, but who had very little influence on him, he could only depend on his mother's earnings, who became a postmistress in Kisoroszi. Their situation became more stable both financially and emotionally when his mother married the local reformed pastor-teacher, Géza Kovács. With him, Bereczky developed a healthy and mutual, warm and loving relationship. Géza Kovács's positive example and caring attitude were crucial for the young Bereczky to become a healthier person and a pastor himself (Pályi 1966: 388).

While his biological father acted cold and distant, he still wanted to exercise control over his illegitimate son. When Bereczky was just a three month old baby, he was basically kidnapped with the help of other Roman-Catholic relatives and baptized at the Bakáts tér Parish Church according to RomanCatholic rite. The fervent Catholic Apponyi sent regular financial support to his son, and in turn, he forced him to attend the Piarist high school of Vác. It was a great relief for Bereczky when his stepfather arranged his transfer to the Reformed secondary school of Kunszentmiklós. [In the birth records of the St. Francis of Assisi Parish Church at Bakáts square (Budapest) the children who have been born outside of marriage were labeled with the abbreviation 'ttlen' while the legal children with the 'törv'. abbreviation. In the case of Albert Bereczky, the unique classification of 'Törvényes az állam törvényei szerint' ('Legal according to tha laws of the state') can be seen. According to the local parish priest this could refer to the unclarity of Bereczky's origin. The birth records refer to Albert Apponyi as godfather. ii. The earliest state security reports took it for granted that Bereczky was Apponyi's son: Állambiztonsági Szolgálatok Történeti Levéltára (henceforth ÁBTL), 3.1.5. O-9047, 61. 22.03.1946.; iii. According to Gyula Muraközy Bereczky personally confirmed on several occasions that he was Apponyi's son: ÁBTL, 3.1.5. O-9047, 388-396. 22.06.1956; iiii. Kardos István in his memoirs about his father, who was Albert Bereczky's classmate, mentions that the adolescent Bereczky boasted with his aristocratic origins at the Kunszentmiklós Reformed High School. iiiii. On a recent public event one of Albert Bereczky's grandsons also declared that in his opinion his grandfather's father was Count Apponyi ('Világ Egyetemi Előadások' Lectures at the Budapest-Pasarét Reformed 
Congregation on 7 June 2019). Bereczky never called Endre Bereczky his 'father', he usually referred to him as the 'old-Bereczky'.]

His troubled childhood, his conflicting father figures, his financial, emotional and social instability opened him for experiencing spiritual conversion, but first, he looked for remedy in something else. Having finished the secondary school, he got to the Reformed High-School of Kecskemét, where he associated with older boys who were bad influence on him, which manifested in carouses and heavy drinking. He lived through the famous Kecskemét earthquake of 1911 (July 8th), which happened at 2 in the morning, while he was partying with his older friends. Interestingly, this 5.6 earthquake, in which the quarter of Kecskemét's houses have been destroyed, did not seem to make a deeper impact on his spiritual forming. At least, he did not even mention it in his sermons or speeches later. Nevertheless, her mother was in shock. He did not want to let his son stay in Kecskemét anymore and offered him to choose any other reformed high school to finish his studies. Her motive for transfer could have been that she wanted to remove her son from the proximity of his drinking buddies. Bereczky admits that he understood her mother's will as a punishment, so he chose the farthermost college, Pápa, just to take revenge on his mother. The 17 years old Bereczky got into Pápa in his last high school year, and that city became for him one of the most significant places of his life. In Pápa he found new drinking buddies, but in this case, these new friends were seminary students, like Géza Kiss, József Zákányi, Imre Szabó, and Zoltán Tildy (Szabó 2011: 601).

Although he was a regular attendant of worship services from his early childhood as a pastor's stepson and a pupil of reformed high schools, and he also deeply admired Bishop Sándor Baksay's eloquence at Kunszentmiklós, Bereczky received his first profound spiritual impact by the Word of God at Pápa. As a high school student, he was obligated to attend the 'boring' events of the 'Society of Confirmation Youth' when they had a guest preacher in the person of János Victor, then 23 years old secretary of MEKDSz, the evangelical movement for students. As Bereczky describes his experience: 'The first time in my life the power of Jesus Christ's personality stunned me like an electric shock. The young theologian student secretary spoke about Jesus Christ in a manner that I told thereafter: whom this young man talked about, we have never heard anything before' (Bereczky 1965: 15).

It is interesting that Bereczky did not refer to this intense experience in his sermons and speeches later. The only known source of his spiritual forming is a short memoir published in the journal Református Egyház in 1965, only one year before his death. It has the misleading title 'The church lives in her congregations' (Bereczky 1965: 15), but it seems to be a piece of a never finished autobiography. While Bereczky seemed to have a vain personality, as a Barthian theologian, he could restrain himself from sharing too much 
personal detail in his sermons, which explains his silence about this first more profound spiritual experience.

Another account of this experience can be found in the funeral sermon of János Victor. Bereczky and the five years older Victor became friends and even in-laws later. Victor acted as a spiritual and theological mentor-a new father figure-for Bereczky, whom he also chose as his deputy after he became a bishop. According to Victor's son, István, in the family circle, Bereczky frequently said that he converted by the sermon of Victor (Hosszú 2011: 16). Victor's early death happened at the time of the critical low point of the Bereczky church government in 1954 (Pap 1992: 105). Bereczky, in his funeral sermon, reveals even more details about Victor's influential sermon (Bereczky 1961: 67). Accordingly, Victor preached about the capture of Jesus at the Gethsemane (John 18): 'I was eighteen when I heard him the first time-he was not much older than me. From then on, I always see Jesus the way he described him: the way he stepped forward from among the trees of the Gethsemane-the way he said to the officers: "I am He" — the way they drew back and fell to the ground in the presence of His power and might' (1961: 68).

In another eulogy, in which Bereczky compares János Victor to John Mott, one of the most influential promoters of the revivalist movement, he states: 'I received my very first experience of Christ as an eighth-grader in the school year of 1911-12 from János Victor. This was followed by an unbroken friendship of almost 40 years. This always belonged to the most precious treasures of my life' (Bereczky 1961: 309). [Victor János Jr.'s son, János, married Bereczky’s daughter Piroska. See also in Hosszú Gy (2011) Victor István életinterjú, 16.]

Nevertheless, this first important spiritual experience was not the main reason why Bereczky applied to the seminary. He admits that this experience faded away quickly and he decided to be a seminary student mostly by the urge of his older seminary friends (Zsindelyné 1978: 16). Additionally, he wanted to avoid military service, which proved to be a fortunate move, considering the following years of war. It is also mentionable her mother wanted to send him to the 'Keleti Akadémia', the prestigious school for diplomats, because she hoped her son would follow the footsteps of his alleged biological father. Bereczky notes that his decision for becoming a pastor made his stepfather very happy.

It is interesting to see, how at this point he resisted to conform the ideals of his birth father and conforms the ones of his step-father instead. According to an unverifiable urban legend around this decisive time, Count Apponyi also met his birth-son in person and promised that he would support his diplomatic career. When Bereczky revealed that he wants to follow the footsteps of his stepfather becoming a pastor, Apponyi told him: 'You are going to be 
nothing. We won't see each other again.' Considering Bereczky's strong compulsion to conform towards his birth father, it is interesting to see Bereczky's strong interest in foreign policy. As a Member of Parliament, he became the Chairman of the Foreign Affairs Committee in 1946, not to mention his interest in the work of the World Council of Churches. Muraközy Gyula indicates that Bereczky secretly always wanted to be a Foreign Secretary $[A B B T L$, 3.1.5. O-9047/388-396, 22.06.1956.], a dream which was later fulfilled by his chief rival, Bishop János Péter.

During his seminary years, Bereczky went through another formative spiritual experience that he highlighted as 'conversion'. Bereczky sorted the seminary students of Pápa into three categories. He did not belong to the first group, the 'drinkers', since he-as he argued-already went through that during his Kecskemét years. The second group was the group of the bornagain students, the 'saints'. This unpopular group was always targeted by the sarcasm and ridicule of the others, so he did not want to associate with them either. Finally, he joined the prestigious literature circle. One of their teachers, József Pongrácz, an advocate of revivalism at the seminary, persuaded Bereczky and Tildy to participate in the MEKDSz summer camp in Felsőszeli, Upper Hungary. Bereczky does not tell too much about what happened in Felsőszeli, but he admits that the 'summer conference fixed everything in us (Bereczky 1965:16)'. [Apponyi died in 1933, Bereczky attended his funeral. Thi is all what we know about their relationship afterwards.]

Further information about this period can be found in the memoirs of another influential friend of Bereczky, Imre Szabó, whose name is not even mentioned in his life account from 1965 (Szabó 2001: 198). During the Pápa years, Imre Szabó was as close to Bereczky as Tildy. Szabó remembers that he admired Bereczky very much for the sincerity of his conversion. Accordingly, they went through 'the purgation of their sinful and filthy youth' (Szabó 2001: 76, 80, 104, 126, 138, 171, 191, 198, 205, 220, 223, 231, 260, 261, 264) together. After the summer conference, they were ready to take the mockery of their unconverted schoolmates. They attended the Morning Prayer meetings of Károly Nehézy and the Bible studies of József Pongrácz. In November 1913, they even travelled to Pest, just to hear the world-famous evangelist, John Mott, in person (Bereczky 1961: 305).

After his conversion experience, Bereczky became very critical about the moral situation of the Reformed Church. After his conversion, he spent the summer at home in Dunabogdány. Bereczky admits that his conversion made him prideful and vain. His stepfather, who frequently asked him to preach, and who also felt the change in Bereczky's attitude, made him realize that the Reformed Church's moral condition was much worse a generation before. His stepfather convinced him not to despise the current pastors of the church who made a considerable progress since their ancestors. 
Another fine-tuning of his new faith came from one of his professors, Sándor Czeglédy, who asked him to read Calvin's Institutes saying that it was also written by somebody who expressed a very critical opinion about the Church. Bereczky had to report to Czeglédy about his progress in the Institutes in every two weeks. The Institutes laid a massive impact on Bereczky and convinced him that he must work on the revival of the Reformed Church (Bereczky 1965:17). [The two close friends, Bereczky and Szabó, became political opponents in the early 1950s, which resulted in Szabó's coerced deposition from his office as Dean of the Budapest Church County. After Szabó was relocated from Budapest to a remote Eastern-Hungarian village, he died within three years. Bereczky refers to this occasion in his remembrance speech written about both John Mott and János Victor who died around the same time in 1954-1955.]

Apparently, there are not many sources on Bereczky's first experiences with revivalism. His troubled childhood; the emotional and financial insecurity as a possibly illegitimate child; his hypothetical troubled relationship with his biological father; the positive example of his stepfather; his deviant adolescence behaviour, like heavy drinking; all this could make him open for what religion psychologists call ‘sudden conversion' experience (Spilka 2003: 245-247).

However, even if he was proud of his experience waked by János Victor's sermon, he also admits that it faded away, so we can assume that his case more likely exemplifies what psychologists call a 'gradual conversion' experience (Strickland 1973: 265-271). This is the product of a longer incubation process, which results in steadfastness and more commitment toward the Church.

\section{Bibliography}

Barcza J (1999) Egyházunk az 1956. évi forradalom idején és Ravasz László jelentősége. In Barcza J Dienes D (eds) A Magyarországi Református Egyház története 1918-1990. Tanulmányok. Sárospatak.

Bereczky A (1965) A gyülekezetekben él az egyház. In Református Egyház $17(*)$ : n.p.

Bereczky A (1961) Két nagy misszionáriusunk: Emlékezés Victor Jánosról és Mott Jánosról. In Bereczky A (ed) Hitben való engedelmesség. Budapest: Református Egyetemes Konvent Sajtóosztálya.

Bereczky A (1961) Victor János temetése. In Bereczky A (ed) Hitben való engedelmesség. Budapest: Református Egyetemes Konvent Sajtóosztálya.

Coe GA (1916) The Psychology of Religion. Chicago: University of Chicago Press. 
Gombos Gy (1992) Szűk esztendők. In A történelem balján II., Budapest: Püski Kiadó.

Hosszú Gy (2011) Victor István életinterjú. August-November, Hejce: Judit Kádár (ed), digitized manuscript.

Kiss R (2006) Bereczky Albert lelkipásztori, püspöki működése. In Kósa L (ed) Reformátusok Budapesten, volume 1. Budapest: Argumentum, pp. 601620.

Kiss R (2006) Fejezetek a budapesti reformátusság második világháború utáni történetéből az 1970-es évekig. In Kósa L (ed) Reformátusok Budapesten, volume 2. Budapest: Argumentum, pp. 1369-1421.

Kiss R (2006) Református ébredés Budapesten. In Kósa L (ed) Reformátusok Budapesten, volume 2. Budapest: Argumentum, pp. 1343-1369.

Kovács Á (2019) A Critical Reflection on Conversions or Journeys from Christianity to Communism. In Kovács Á, Shin J (eds) Nationalism, Communism and Christian Identity. Protestant Theological Reflections from Korea and Hungary. pp. 141-162.

Ladányi S (1999) Vázlatos történelmi áttekintés a Magyarországi Református Egyház közelebbi múltjának alakulásáról. In Barcza J and Dienes D (eds) A Magyarországi Református Egyház története 1918-1990. Tanulmányok, Sárospatak pp. 101-139.

Nagy E (1994) A Budapest-Pozsonyi úti 'Hálaadás' templomának lelkésze Bereczky Albert mint egyházkormányzó. Confessio 15(*): 105-121.

Kovács J (2012) A paraszti társadalom felszámolása a kommunista diktatúrában. A vidéki Magyarország politikai társadalomtörténete 1945-1965. Budapest: Korall.

Pályi V (1966) Nehéz esztendők és az első országos kezdeményezés Dunabogdányban. Református Egyház 18(*): n.p.

Pap L (1992) Tíz év és ami utána következett 1945-1963, Bern: EPMSZ.

Scobie GEW (1973) Types of Religious Conversion. Journal of Behavioral Science 1(*): 265-271.

Siba B (2009) A megtérés pszichológiai háttere. Református Egyház 1(*): 20-24.

Siba B (2018) Pasztorálteológia. A református lelkészi hivatás vizsgálata interjúk tükrében. Budapest: L'Harmattan-Károli Gáspár Református Egyetem.

Spellman CM, Baskett GD, Byrne D (1971) Manifest Anxiety as a Contributing Factor in Religious Conversion. Journal of Consulting and Clinical Psychology 36(*): 245-247.

Spilka B (2003) The Psychology of Religion. An Empirical Approach, New York: Guilford Pub.

Strickland MP (1924) Psychology of Religious Experience. New York: Abingdon Press.

Szabó Imréné, Szabó É (ed) 'Ég de meg nem emésztetik'-Szabó Imre a Budapesti Református Egyházmegye Első Esperese Naplók 1914-1954. Budapest, Budahegyvidéki Református Egyházközség. 
Zsindelyné Tüdős K (1978) Arcképek. Budapest: Református Zsinati Iroda Sajtóosztálya. 